\title{
Security Issues and their Implication on Albania's Road to European Integration
}

\author{
Etleva Babameto \\ PhD Candidate at the State University of Tirana \\ Email: eva_babameto@yahoo.com
}

\section{Doi:10.5901/mjss.2014.v5n23p362}

\section{Abstract}

Among considerable international organizations providing security in Europe, such as NATO, EU, UN, WEU, OSCE, etc., this paper covers evolution of security issues in Albania on the context of NATO and EU dynamics with regard to their crucial roles in providing security, peace and stability. Why are NATO and EU so important to Albania? Albania was the first former communist country which immediately following its first multiparty elections in 1992, requested NATO membership as the most important and biggest military operation in Europe since the Second World War providing security, which took 17 years to finalize. On the other hand, Albania's EU integration as an important political, economic, social and legal process is far more complex and more difficult. Moreover, all successive Albanian governments have always given priority in their foreign policy to NATO membership and EU Integration. For this reason, study of Albania's path to NATO membership and its long road to EU integration, deserves special attention to get insight on the way they have evolved in Albania. Also, of specific importance is the correlation between NATO and EU developments on security-related issues as well as their impact on Albanian international and integrational processes.

Keywords: Security, integration, NATO, membership, reforms, partnership, EU;

\section{Introduction}

The fall of the Berlin Wall, the end of the Cold War, symbolized the end of bipolarity, including the military-political division of the Europe. Taking into account the fact that the anxiety of East-West confrontation has ended, a question may arise: are today, all in Europe, except military threat, free from or protected from other threats?

Truly, a new globalised environment was created where the new nature of security in Europe, the large number of states involved in these changes, the short duration of time in which changes took place and the massive political shifts, necessitated an increase of international organizations involvement in Europe in security-related issues due to new threats, totally unpredictable and uncontrollable by internal potentials of the states concerned.

Following the fall of communism, dissolution of Soviet Union, disintegration of Yugoslavia, and especially after the 11 September 2001 events, it was quite clear now that no country could secure itself on its own but only through close cooperation at regional and global level.

Evidently, the place of security in state policies is not just the function of its historical experience. Security is a primary necessity of individual's existence, social groups, nations and states. The essential part of this case is not exclusively survival, integrity or sovereignty, but security of development, guarantee of defense, uphold of individual's identity, society and nations. Without this fundamental part, no economic development, stabilized democratic state, modern education, openness to the world to benefit from civilizing achievements of other nations, is viable.

Therefore, Albania was eagerly determined to joint different international organizations as a way of opening to the west although it lacked the necessary knowledge and capacities to do so and immediately determined her orientation towards future Atlantic and European values. Being the most self-isolated former communist country in Europe, Albania did not lose time to open her doors of relations and cooperation with international organizations, such as NATO, EU, UN, WEU, OSCE, etc.,

More specifically, shortly after the country's first multiparty elections in 1992, Albania requested NATO membership, set to her long road of domestic reforms, changes, developments, regional as well as international cooperation, EU integration, which in turn were to strongly influence in the course of her progress towards democratization, towards a more secure country in a better world. 


\section{The Security Concept}

It is a known fact that security has always been a basic concept in international relations. It is accepted that it includes being secure (free) from threats of fundamental values (Wolfers, A. 1962, p. 147-165).

As an important historical and social notion, it was born, developed and adapted with political and historical changes of the human society since its beginning. As such, the term "security", has existed since the emergence of first states. Some scholars have even come to the conclusion that the origin of state is linked with the protection of national security (Cela, A. 2006, p. 104-109). States have invested in strategies to provide the necessary security to exist or survive. Some powerful states have used the strategy based on military power meanwhile some others which found themselves in less favorable political, military, economic and geographical circumstances, have used the strategy of neutrality.

According to this historic definition, the most classical threat in the human history is state to state violence. Aware that the world never became secure, the concept of security has been mainly concentrated on creation of policies and defensive mechanisms to avoid, prevent and even win in inter-state military confrontations.

As a matter of fact, during $1945-1990$, security used to be interpreted as simply related to the military security of a state (Hard Security). Therefore, traditional security is focused on the state and on this context the danger or threat comes mainly from a foreign aggressor and not from any internal clashes (Meidani, R. 2006, p. 78-92).

Considering the important changes in terms of political, social and military aspects in the last century, it is noted a transformation of "security" depending on the specific environment it is developed and materialized. Global security is no more a matter of hundreds of actors, but a matter of thousand and thousand actors who do not know state boundaries, but are prone to transfer the conflict into other states or regions through land, sea or air.

Thus, "traditional security" has been replaced by "human security" focused on individual (Meidani, R. 2006, p. 7892), on the necessity to feel secure not only from foreign aggressor, but from internal conflicts, terrorism, organized crime, trafficking, environment pollution, poverty, unemployment, unmanageable migration, social tensions; otherwise called Soft Security-related issues (Jazbec, M. 2007, p. 179), etc.

It is important to stress that although these definitions of security as traditional and human are not the same, there is not a clear cut division between them, they are related and they both do not occur with the same intensity everywhere. For instance, in Europe, Hard Security is not so important actually, but it is very crucial in some other regions of the world.

However, we cannot say that Soft Security was born all of a sudden in new circumstances and places as well. Its elements have existed and have been essential for many years. Problems such as state failure, corruption, economic crisis or even organized crime are as ancient as the wars and arms themselves. Security elements are not implicated worldwide in the same ways and parameters just because each region has always had its own specificities.

Approaching "security" notion into global level makes up its direct relation with NATO as the most powerful on security-related military organization in the world which has always been subject to the transformation process since it was established in 1949 as a defense organization against plausible Russian aggression (Goldstein, S. J. 2003, p. 107). It is the case to mention that this transformation process has gone too far: from dealing with Euro Atlantic Security to Global Security which means adaptation to the changing security environment and different kinds of threat (Jazbec, M. 2007, p. 123) with very strong relations with Europe thus driving Albania (among other states) to focus on Euro - Atlantic Security process and integrate into European security developed structures.

\section{Albania and NATO}

\subsection{Albania, her National Security - a unique case}

After the end of the Cold War, Albania emerged as the most isolated country. While the other free East European countries embarked on reconstructing their life through their democratic institutions, Albania had neither democratic model of her own to follow, nor inherited political culture (Dawisha, K. Parrot, B. 1997, p. 291-314). At that period, Albania found itself under specific conditions and circumstances: a totally paralyzed economy, record unemployment, extreme poverty never seen in Europe with accordingly unmanageable emigration along with the relevant problems.

In addition, it presented a massive Albanian population throughout the Balkans beyond the Albanian state boundaries. Hence, the Balkans integration into the European mainstream, would have a vital importance for the Albanians who gradually would exceed that historical frustration of being a divided nation into several different state territories (Fuga, A. 2004, p. 354-357). In an area with symbolic state boundaries, they would freely and extensively communicate by developing entire and coherent economic, cultural and social dynamics among them (Fuga, A. 2004, p. 
355).

\subsection{Specific characteristics}

Different from other eastern countries, except former Yugoslavia with its non-alignment policy (Dawisha, K. Parrot, B. 1997, p. 147-153), Albania was not a member of the Warsaw Treaty. In this case, her national security was neither influenced, nor conditioned by the dissolution of that Treaty in 1991 as it was the case with the other soviet block countries.

Although it was not part of either block, Albania's philosophy of national security as a totalitarian country, for decades had been based on "hard security"/ military forces. Their moral and technological content was in such a totally extreme low level as to make the protection of her borders and sovereignty unthinkable and improbable.

Geostrategic situation was one of the worst considering that war in former Yugoslavia was near its boundary. The independence issue of Kosovo was to have a significant effect on Albania's road to NATO and EU integration as well.

The events of the pyramid schemes in 1997, which made Albania fall into chaos, social, economic and political instability, halted and slowed its reforms pace as well.

A positive peculiarity is that Albania had no ethnic or religious conflicts which could provide insecurity and instability directly influencing the country's security and add fuel to regional issues during the 1990'. It did not have any territorial conflicts with its neighbors either. While territorial and ethnic conflicts in the Balkans threatened to "Balkanize Europe" instead of the perspective to "Europeanize the Balkans" thus bringing NATO into their stage (Kadare, I. Simic, P. Frckoski L. Hysa, Y. 2001, p. 41), Albanian State has respected the sovereignty of neighboring countries by not interfering into their internal matters and following a peace policy. On the other hand, regional cooperation was almost lacking and on these conditions it was impossible to rely on internal elements (including defense system and military capacities) for national security.

\section{NATO and Its Open Door Policy}

\subsection{Membership Action Plan (MAP)}

The process of NATO enlargement constitutes a major contribution to the security issue (Thissen-Schotgerrits, M. 1999, p. 28). The open door policy which is not a single event, constitutes a good incentive for countries aspiring to join NATO implying that they have to fulfill certain criteria, which entail costs and benefits. Thus the message is clear: NATO is committed to admit new members.

To help aspiring Partners prepare for future membership, NATO proposed and launched in the Washington Summit in April 1999, the MAP (www. assets.opencr.com/rptsRL34701_20090414.pdf) initiative in which Albania became one of its aspiring members. Although it is not an invitation for membership, this program assists by asking to provide information for the reforms undertaken not only on pure defense/military issues but also on general political, economic, defense, security as well as legal issues. Joining NATO is not just about military or defense issues. The aspiring country defines the objectives, priorities and timelines according to its needs and necessities for the preparation for membership requirement by means of discussions with the Council of North Atlantic. This in turn prepares an annual Progress Report for the respective country. Until its final membership (14 April 2009), Albania has had 9 rounds of talks and took the invitation for NATO Membership on the $4^{\text {th }}$ of April 2008.

\subsection{Criteria on NATO Membership}

NATO membership is not a list of defense and military rules to fulfill. Explicit or implicit prerequisites for joining NATO are political, economic and military including a rational argument over the NATO strategy:

a) Represent a democratic, political system based on a market economy;

b) Respect human rights and minorities;

c) Settle out territorial, ethnic disagreements, etc. with their neighbors;

d) Promote welfare and stability;

e) Ensure democratic oversight of their armed forces;

f) Provide opportunities and willpower for military contribution into the Alliance in order to ensure inter-operations with the other member countries

g) Reallocate a sufficient level of expenses for defense in order to fulfill their commitments for collective defense 
in the future (Shehu, M. Cani, 2008, p 37).

But, fulfillment of these criteria, integration into NATO, involves certain costs and benefits, namely:

Direct military costs comprise:

a) Membership cost-contribution to join NATO;

b) Costs related to civil and military representation into NATO;

c) Costs related to commitments of troops into joint operations;

d) Costs for participation into joint activities of NATO; (seminars, conferences, joint exercises, the role as a "hostcountry", etc.)

e) Maintenance of defense budget at a certain level to realize the armed forces according to NATO standards;

f) Costs on development and infrastructure/territory adjustments;

g) Cost related to legal, procedural and organizational regulations (Institute for Democracy and Mediation, 2008, p. 36-37).

Non-military costs comprise:

a) Political cost; (despite the polemics in reducing a nation's sovereignty, there is lack of public support, a potential cost to terrorist attacks, fulfillment of NATO and EU standards for the electoral process and judicial reform)

b) Economic cost; (cost of restructuring and further liberalization of the economy, promotion of business, privatization in economy, improvements in social insurances system, reforms in health and education sectors, etc)

c) Social cost; (the fight against corruption, organized crime, trafficking of weapons, narcotics and human beings)

d) Costs of infrastructure (improvements in road infrastructure, energy, telecommunication) (Institute for Democracy and Mediation, 2008, p. 46-49).

On the other hand, in relation to cost-benefit ratio, it is important for a state to clearly define its primary vital goals from which it will benefit at any cost.

a) Concretely, Albania benefits first of all values of democratization, stability and freedom. The democratic reforms in every economics field, trade, political area, military etc, in the frame of meeting membership criteria makes up one of the most motivating political actions for our country. NATO membership increases political stability and reduces possibilities for instability, which is very important to our national interests. The experience so far, has proved that political instability, brings about failure of institutions, lack of social peace and public order, failure to achieve a political consensus, and infringes Albania's prestige into international level (The National Security Strategy of the Republic of Albania, Defense Ministry, 2005, p 27-28).

b) Security and economy are closely interconnected. Security is a precondition of development (European Security Agenda, 2003, p. 2). A secure environment influences the attraction of investments and therefore economic increase. Economic level is inextricably linked with corruption, unemployment, organized crime, poverty, trafficking, illegal migration, etc. In a positive level, it influences businesses to freely act, independent of the state, increases employment level closely linked with reduction of illegal emigration, reinforces national identity, etc.

c) At regional level, Albania becomes a stabilizing factor in the region, by increasing Alliance's influence on this part, by cooperating with other Balkan countries where isolation, lack of cooperation, animosities, wars, conflicts belong to the past.

d) NATO membership implies consolidation of Albania's Armed Forces and their transformation according to NATO criteria. Participation into multilateral missions serves as an instrument to generate effective security, as a cornerstone for Albania's armed Forces, their potentials and capacities.

e) It is very important to highlight that NATO membership enables Albania (actually a member of NATO) to take part in decision-making process of the Alliance on security-related matters.

\subsection{Regional cooperation: bilateral and multilateral relations}

Regional cooperation is a precondition to NATO and EU Integration which is the main strategic goal of all SE European countries. This strategic goal is vital for both the region as a whole and for each individual state where each one understands and accepts the necessity to make up for all types of confrontation and conflicts with cooperation (Jazbec, M. 2007, p. 97). This means that countries in the region are not willing to rely on conflict as a means to resolve disputes but are committed to accept and participate in possible kinds of cooperation.

Neither are they bound to pose a threat to each other any more but conversely are bound to address risks and 
challenges together. Doing so, they provide more stability and security in the region.

This means that countries concerned share the same values, have common goals, understand and respect each other, all these translated into concrete relations.

In terms of bilateral relations, Albania has signed with all the countries of the region agreements including joint national and multinational exercises, visits between armed forces, assistance for short-term and middle-term qualifications of the personnel, exchanges of experience and information, assistance for improving the logistical support, etc. With some states cooperation is greater and involves assistance for the restructuring of our Armed Forces, raising the operational capacities and improving the infrastructure of our Army, drafting main documents and legislation (Demi, $L$. 2006, p. 74-75), etc.

In relation to multilateral cooperation, among many of them, one of the most important is the Adriatic Charter (Mustafaj, B. 2006, p.21-23) signed in Tirana, Albania, May, 2003 between Albania, Croatia and Macedonia, a partnership initiative fostering intensification of domestic reforms, regional cooperation, which alternatively promote the stability and Euro-Atlantic integration of the countries concerned and other countries of SEE.

In the framework of accelerating the three aspiring countries integration into NATO, they have held high-level meetings, namely at presidential, parliamentary, ministry, chiefs of Headquarters of relevant armies, other meetings at expert level continuing with drafting and implementing annual programs to increase the capacities and interaction among countries. One of the first contributing results was the formation of Joint Medical Staff which participated in Afghanistan.

Another important multilateral cooperation is the South East Defense Ministerial process (SEDM) signed between SEE countries and US aiming at contributing to regional security and stability and enhancing regional cooperation between countries that have common security goals. A positive result of this cooperation is the South East European Brigade (SEEBRIG), a truly multinational regional force in SEE (Baraj, B. 2006, p. 55-57).

The Stability Pact with its Working Table III concerning security and defense matters, contributes in this aspect covering matters such as demobilization of army officers, small arms control, mine clearance, disaster preparedness and prevention. It also covers issues such as police training, organized crime and corruption (Phinnemore, D. Siani-Davies, P. 2002, p 176).

\subsection{Approach of Albania-NATO relations on phases: Reforms undertaken}

Relations between Albania and NATO (Information regarding data in this part is taken during an interview with Mr. Agim Fagu, Director of NATO Department at the Ministry of Foreign Affairs) date back on March 22, 1992; prior to ideological changes at that period, nothing could be said and done regarding official relations between Albania and the Alliance. As a matter of fact, the democratic government declared openly its ambition for Albania to join the Alliance; moreover this approach was pretty soon to become on of the main priorities of its foreign policy. Due to total professional lack of NATO's policies in such relations and having no restrictions conditioned by both internal and external circumstances, the Albanian government tried to make up for the loss of time. Relevant to this situation, a foreign American diplomat of NATO who had participated in a multilateral international meeting, stated that he had been deeply amazed by a high Albanian official articulating without hesitation Albania's wish to become a NATO member. Obviously, the other part (NATO), had posed no signs of such "impatience", since that policy (?!) was not at all in the Alliance agenda in relation to eastern countries at that period.

The first step to be undertaken was inclusion of Albania into NACC (North Atlantic Cooperation Council), (NACC became a reality on 20 December 1991 in the meeting of 16 Alliance members and 9 Central and Eastern European countries, after the proposal made by the Heads of NATO members in the Rome meeting in November 1991. At that time, NACC formation was one of the very important steps to approximate eastern countries with NATO) in June the same year, namely three months after the new government was formed, which offered Albania opportunities to be informed about the Alliance, its programs and reforms that had to be undertaken, mainly in the defense field. However, despite the westerns attitude, our foreign policy insisted on its rhythms to join the Alliance. Therefore, in December the same year, Albania submitted its official request to gain NATO membership.

One of the most important phases of NATO - Albania relations (especially reform on military), was inclusion into PfP (Partnership for Peace) since its foundation in 1994, followed by IPP (Individual Partnership Program). Its goal was to increase inter-operational ability of Armed Forces with NATO, enhance the transparency of the budget and defense planning and increase the capability to participate into peacekeeping operations through joint planning and training.

Based on this document, Albania signed in Brussel on 19 June 1994, along with other PfP countries an agreement about the status of the Armed Forces. Although it did not offered NATO membership, PfP was nevertheless appreciated by eastern countries, including Albania as well. 
The period following PfP was characterized by an evident economic, political and military progress, although it was clear that the actual levels achieved, especially political (establishing democratic institutions, approximation with European laws, human rights) and military (reforms, structures, operational abilities) were far from objectives as compared with other countries included in the program.

Of special importance is the "Study on National Enlargement", released on 28 September 1995, which constituted the first Alliance decision to open a process that would guarantee NATO membership once certain criteria were fulfilled. Some of these criteria concerned a stable political and democratic system, stabilized legislative and free vote institutions, respect for human rights and individual freedom as well as democratic control of the Armed Forces. Also, some of these criteria asked for readiness and unconditional approval of common defense and establish NATO forces and its installments into territories of countries concerned, approval of NATO strategic concept, will for inter-operational abilities, etc.

Following the events in March 1997, Albania stepped backward thinking of NATO membership as a lost wish and opportunity. It learned that the road towards democracy necessitates real democratic reforms, the rule of law based on uncorrupted institutions as well as the importance of Soft Security, to the national security of a country.

Nonetheless, In July 1997, NATO decided to transform North Atlantic Cooperation Council into Euro Atlantic Partnership Council (EAPC) enabling the participating countries (among others, was Albania as well) to open their missions in Brussels at ambassador level.

But the great change of Albania's progress towards NATO was marked in the Washington Summit in 1999 where MAP program was introduced for the first time asking the aspiring country for NATO membership to focus on five main fields: Political-Economic, Military Defense, Defense Resources, Security in information and Legal Matters. In the frame of this program, as above mentioned, Albania has had nine rounds of talks revealing its progress.

The Military Strategy set three main goals of defense reform, namely: 1- develop a professional army according to Alliance standards, 2- reduce the number of conscripts and 3- increase defense budget, which covered structure, legal basis, managing systems, defense resources, system of education and training of armed forces. Also, three areas for consideration of defense reform were: 1-defense restructuring and reform on defense management practices and institutions, 2- development of defense capabilities required to meet both new and traditional defense-related challenges, 3- action that will increase country's ability to contribute to NATO -led crisis response operations (Jazbec, M. 2007, p. 77).

Accordingly, as it is already known, Albania took the invitation for membership on 4 April 2008 and finalized its full membership on 14 April 2009 - a great event for a people who had given massive support since the very beginning of the respective process.

\subsection{The role of Albania as a provider of security - the way ahead}

Following a peaceful policy in the region and becoming a full member of NATO, Albania becomes finally a provider of security and stability and has the opportunity to participate and act as a co-decision maker in international and integrational processes. A small state thus becomes recognizable; The Albania's international position becomes more solid, enjoys a greater level of acceptability and security. Not only it guarantees its internal security but serves as a provider of security and stability in the broader region stressing the fact that the continuation of close cooperation with other countries in the region, no doubt contributes to more stable development and more security networks.

From another viewpoint, it is known that problems and concerns of Balkan states are closely interconnected and relevant to the region's complex and changing security environment. With the Albania (Croatia as well) NATO membership, the region is more strongly than ever bound in a firm security structure which in turn is able to produce more security than it was the case in the past. So, there is an inseparable interdependence between development and security - no development without security; in other words: the more countries are integrated the wider is the area of security and stability and therefore the greater the possibility for other countries to integrate.

\section{Nato-Eu Strategic Partnership and the Balkans}

\subsection{Security in the western Balkans: A general overview}

Although countries of the region undergo different phases of integrating efforts, they all describe security in the Balkans in a similar way characterized also as a changing dynamics, sometimes even unpredictable. Unanimously, they consider NATO and EU as the main actors of fostering stability and security in this region. Through regular meetings between EU 
Political and Security Committee and the North Atlantic Council (NATO-EU Relations, Handbook, 2001, p. 103), consultation and cooperation is held on concrete topical issues about the situation in the Balkans, where they have revealed the common objectives of these countries, their values and have addressed issues and the need for regional cooperation; the result - a region which provides more security and stability than in the past although much more needed to be done.

On the other hand, following developments in the Balkans during the last two decades, it is noted that each country has developed its own policy of National Strategy which is a document describing the way security is offered to the citizens and its own state.

In the case of Albania, the basic missions of the National Security Strategy of the Republic of Albania, are as follows:

- Exercise of the sovereignty of the Republic of Albania;

- Protection of independence and territorial integrity;

- Protection of life and wealth;

- Continuous democratic development and economic prosperity;

- Protection of dignity and national values;

- Membership in the international structures of security (Albanian National Security Strategy, Defense Ministry, 2005).

\subsection{The perception of western Balkan countries on security}

Considering the importance and the special role of security, documents of National Strategy for each country (On the development of National Security Strategy, 2007, p. 54) describe security in this region partially in a similar way and partially with differences. So according to Albanian Security Strategy, "Albanian factor", makes up a very important element of security. For Croatia, it is "the most worried part of the continent", for Macedonia "the least stabilized" in Europe and for Serbia "less stabilized" where the viability to use force has not disappeared. Based on these definitions, this region is perceived as a rather important "crossroad" between continents playing a "bridging role" (On the development of National Security Strategy, 2007, p. 54), but implying that this is still a problematic and unstable region.

As above, it becomes necessary to highlight different viable threats as to security which are both internal and external ones and need to be addressed.

As internal common threats, could be identified: organized crime, terrorism, disaster and transition process-related problems. Meanwhile, external possible common threats could be identified: possibility of armed conflicts in the region, inherited past conflicts/historical factors, lack of regional stability and crisis, transition problems, intolerance, organized crime and terrorism (On the development of National Security Strategy, 2007, p. 54).

Taking a look at both kinds of possible common threats, it would be unlikely that each Balkan country challenge such issues on its own, except close cooperation at regional level. Since these threats are more or less relevant to all Balkan countries, cooperation among them is very important to use common sources and means for minimizing those threats.

Consequently, it should be stressed that during the first decade after the disintegration of the Federal Republic of Yugoslavia, the region experienced conflicts, tensions, ethnic, cultural, religious and local divisions. However, after the 2000', due to successful involvement of international actors, this landscape changed where it is evident that the whole region is no more that of the past decade but shows less problems and unresolved issues, reflecting thus more stability and security.

\section{The Impact of Security on Albania's Eu Integration}

\subsection{A general assessment of European security process in the western Balkans}

Security is very important regarding the process of NATO and EU enlargement. If a country provides security for itself, it implies stability, development, prosperity, functioning economy, protection of human rights, security at local and regional level, security at international level. Political security, economic security, military security, social security and environmental security are closely interconnected and mutually dependent on each other and make up the environment of a country security (Shiroka, S. 2007, p. 116-118). More specifically, the very principle of EU existence is a secure Europe in a better environment.

In this context, integration into EU mainstream has been a common priority for all Balkan countries. This is a dual 
process in which both parts have their say. The countries aspiring to join Europe must meet the Copenhagen criteria (George, S. Bache, I. 2001, p. 413) as the principles of the enlargement process. These criteria constitute: Political institutions that guarantee democracy, rule of law, human's rights, respect for minorities; Economic: - existence of a functional market economy and the capacity to face up the competing pressure with EU internal market forces; acceptance of acqui communiatire - capability to undertake obligations of membership. More specifically, the Stabilization Association Process (SAP) which started in 1999 (www.ec.europa.eu/enlargement/index_en.htm), remains the framework of the European course of these countries (Poysari, P. www. Esdp-Course.Ethz.Ch). SAP constitutes three main goals: 1-Stabilisation and transformation into market economy, 2- foster regional cooperation, 3- membership perspective into EU.

Since regional cooperation is a precondition for integration into NATO as well, it is important to highlight that in this framework, SAP participating countries into regional cooperation are committed to promote concrete objectives and initiatives in the field of regional trade liberalization, free movement without visas, creation of regional trades for energy and gas, development of transport, energetic infrastructure and telecommunication, protection of environment and water management, cross-border and parliamentary cooperation where SAP operates as a dual process (between EU and SAP members) and a regional one (among SAP members themselves).

Turning back to Copenhagen criteria for EU membership, it should be mentioned that the word "security" is not expressively mentioned although this does not prove it is irrelevant. But this is comprehensible first due to the change of perception of "security" concept in the post-Cold War era. Also, EU itself was undergoing modifications to its identity of security while adapting in the transforming process throughout Europe after the 1989'.

However, conditionality is closely linked to the underlying nature of the security concept as a constant factor in the definition on democratic governing of institutions formulated in the Copenhagen criteria. It implied all groups of the society capable of using institutions to administer, govern, supervise and control them, or which play their role in the development of security policy and offer security for their country (Law, D. 2008, p126).

In this new environment, European security processes have undergone intensive and substantial change being primarily affected by EU and NATO enlargements besides other international organizations memberships. Accordingly, the European security process entails three main characteristics: 1- complementarity: Going back to political developments in the Balkans after the Cold War, it must be admitted that security could only be achieved through complementary activities of national and international subjects, the latter being indispensable and predominant. With their different approach to security issues as far as the mechanisms, different international organizations are capable to deal with the majority of security threats within the region. 2-Complexity since we can observe many participants on various levels. This strengthens a multilateral approach and tends to exclude the possible solo action approach. 3- The complicated nature of these processes resulting from a) overlapping of both organizations' members, b) relations of member countries towards applicant/candidate countries, c) to other countries (PfP members and aspiring ones) (Jazbec, M. 2007, p. 47-49).

Considering these three characteristics, it is apparent that only through cooperation, complementarity of action, trust and transparency, the aspiring states to join EU, can find a secure environment to go through regional cooperation where despite the approach of the Balkans as a whole, each one is assessed according to individual pace of meeting the set criteria.

After gaining NATO membership, signing and ratifying the SAP process, it implies that Albania has provided a secure environment, which means it has met NATO membership criteria, and concluded SAP. Thus it fosters stability, economic development and prosperity both in its own territory and in the region. This in turn becomes a strong incentive for further enlargement, for EU enlargement as the current challenge of Albania.

\subsection{The effects of NATO-BE relations on security in Albania}

One of the main characteristics of NATO transformation is its cooperation with other international organizations. Concerning NATO-EU cooperation, until the year 2000' there were no formal relations between the 2 organizations but following the long-term crisis in the Balkans in 1999', after the NATO intervention in Kosovo www.brook.edul views/articles/daalder/19990920FP.htm), perhaps the most successful cooperation between NATO and EU has been put under way. For Europe it was clear that what happened in Kosovo constituted a disappointing engagement of its diplomacy and lessons had to be learned. Furthermore, for both organizations, Kosovo issue regarding its future status was to represent a testing field along with other issues in the then-destabilized Balkan. Accordingly, EU leaders decided to form a European Security and Defense Policy, (D'Arcy, F. 2007, p. 160-166) which in addition to its relevant responsibilities, would cooperate with NATO establishing a range of plausible military missions and defining goals for 
certain capabilities, further leading to their Strategic Partnership.

Having defined the same threats, addressed the same challenges and determined to combine operations with access to their capabilities, it appears the perception of security concept is the same for both organizations - NATO defined it in the Washington Summit 1999 (Handbook, 2001, p. 42), while EU in the European Security Strategy 2003. Their cooperation through complementary actions would make Albania a participant of joint engagement and not just of one. Accordingly, Albania has adapted itself to this environment and has considered this concept in compiling its National Security Strategy. Therefore, it is clear for Albanian National Strategy to define these threats, possible dangers, objectives, mission and priorities in compliance with relevant international organizations and become also part of joint NATO-EU led operations. There is no NATO security or EU security, therefore there is no specific Albanian National Security Strategy relevant to either side of security.

Additionally, following the NATO standards and ultimately becoming a full NATO member, Albania has managed not only to become a provider of security on its own territory but also contribute to different NATO and EU led missions in the region and furthermore.

In this context, worth mentioning is the participation of Albania in an EU -led military mission in Cad, Africa in the summer of 2008, deployment of an Albanian military medical team along with Croatia and Macedonia in Afghanistan, military troops in Iraq, as well as participation in Althea mission in Bosnia-Herzegovina, thus increasing its image as a decent participator and contributor to peace, stability and security not only in its own country but even at international level.

A very important aspect of NATO-EU cooperation with direct implication on Albania's security, is the "Common Platform on Border Security and Management" (Ohrid Regional Conference, May 2003), which as a regional cooperation mechanism helps the western Balkan countries concerned, to tackle cross-border crime, to facilitate trade across borders and to stabilize the border regions themselves in line with EU standards where one should bear in mind that regional integration is offered as a model from outside (Rakipi, A. 2008, p. 29-32). NATO on its part was committed to provide advice to the relevant authorities on the military aspects of reforming and restructuring border security. In so doing, both NATO and EU through their complementary actions, influence to increase security not only within each country but at regional level too.

In this respect, to achieve the objectives of the Common Platform, Albania has approved "The Strategy on Border Control and its Integrated Management" by the decision of the Council of Ministers No. 118 dated 27.02.2003(Rakipi, A. 2008, p. 29-32) whose goal is to further enhance the functioning of national bodies dealing with border security. This strategy is oriented at the implementation of the instruction of the EU pursuant to the principle "open, but secure borders" (Ibraj, B. 2006, p. 41-44).

To this aim, Albania has also taken continuous steps for strengthening its internal security environment (established in Albania's National Security Strategy) which as such serves to provide security outside its borders as well.

As above, NATO and EU criteria represent a close interconnection of economic, political, military, judicial and social spheres, already included in the concept of security. As a result of Albania's performance in all these spheres throughout its long road of reforms undertaken and changes made, following its NATO membership in April 2009, Albania was granted the EU candidate status in June 2014, thus reflecting the progress it has made towards EU integration.

\section{Conclusion}

Changes following the end of the Cold War, marked Albania's road to a new course of evolution. In contrast to long and total self-isolation, it rushed to open to the west and join to international organizations; most important to NATO as the main powerful actor in the world providing security and EU as the symbol of western values, development and free movement.

It took 17 years for Albania to become a NATO member. A long way full of reforms, where in addition to defense and security reforms, all the other political, economic and social spheres of life have been incorporated. To be a NATO member, implies to share common values of democracy, peace, stability, human rights and market economy achieved through persistent efforts, concrete actions, engagement and commitment to undertake the responsibilities for implementing the obligations and meeting the criteria. And Albania did it.

NATO membership provided regional cooperation, a very important factor and a preliminary condition to join NATO. Albania's cooperation with other regional countries, brought more stability and peace, introduced a better picture of the Balkan after 2000', transformed the countries concerned and the region as a whole into a more developed, less problematic and more secure, thus offering a better picture concerning the perspective of Balkan countries for EU integration. 
Moreover, cooperation and relations among international actors, in this case NATO and EU, proved to be crucial. Their complementarity nature increased Albania's involvement into a variety of cooperational and integrational schemes, partnerships and relations promoting its development and security, a security encompassing all spheres of life.

Following NATO membership, criteria set by NATO, turn to be similar and closely intertwined with those set by EU; Therefore Albania's successful and eventual NATO membership and its ratification of SAP agreement, have served as a catalyzer with regard to promoting and accelerating the Albania's EU integration. In this long and challenging road, a very positive achievement is the candidate status Albania received in June 2014. Let's be optimistic...

\section{Bibliography}

NATO - Handbook, (2001). Brussels - Belgium

Jazbec, M. (2007). "Globalizing European Security Processes", "Security and Diplomacy in the Western Balkans", IFIMES

Law, D. (2008). "Governing of Security Sector in the Strategy of EU Enlargement", "Security Issues", Quarterly no. 2, Institute for Democracy and Mediation (IDM), Tirane

Mustafaj, B. (2006). "Karta e Adriatikut dhe NATO", Albanian Agenda for Regional Security, IDM, Tirane

"Security Issues", (2007). Quarterly no. 4, IDM, Tirane

Holm, U. "A question of Space and Security", EU Neighborhood Policy, Danish Institute for International Studies, Working Paper no. 2005/22

George, S. Bache I., (2006). "Politics in the European Union", Oxford University Press

Ibraj, B. (2006). "Reformat e Sigurise Kufitare", Albanian Agenda for Regional Security, IDM, Tirane

Shehu, M. Cani, (2008). "Kostot e Anetaresimit ne NATO", "Security Issues", Quarterly no. 8, IDM, Tirane

Shiroka, S. (2007). "Political and Military Leadership and its Role for the National Security", "Security Issues", Quarterly no. 3, IDM, Tirane

Goldstein, S. J. (2003). "International Relations", Dituria, Tirane

Baraj, B. (2006). "Nje Nisme e Suksesshme Rajonale per Sigurine Kolektive", Albanian Agenda for Regional Security, IDM, Tirane

D’Arcy, F. (2007). "Politikat e Bashkimit Evropian", Papirus

Meidani, R. (2008). "Problems of human security in the Western Balkan", "Security Issues", Quarterly no. 2, IDM, Tirane

Cela, A. (2008). "Civil responsibility on security issues", "Security Issues", Quarterly no. 2, IDM, Tirane

Kadare, I. Frckoski, L., Hysa, Y., (2001). "Ballkani i Jugut", Onufri, Tirane

Phinnemore, D. Siani-Davies., (2002). "Beyond Intervention? The Balkans, the Stability Pact and the European Union", Journal

"Costs and Benefits of NATO Membership", (2008). IDM, Tirane

Fuga, A. (2004). "Shogeria Periferike", ORA, Tirane

"On Development of National Security Strategy", (2007). Toena, Tirane

Peterson, J. Shackleton, M., (2002). "The Institution of the European Union", Oxford University Press,

Dawisha, K. Parrot, B. (1997). "Politics, Power and the Struggle for Democracy in SEE", Cambridge University Press, "Why do we need NATO", (2008). Albanian Institute for International Studies (AllS), Tirane

Kissinger, H. (1999). "Diplomacia", Laert, Tirane

Rakipi, A. (2008). "Week States and Security", AllS, Tirane

Demi, L. (2006). "Sfidat Politike te Sigurise", Albanian Agenda for Regional Security, IDM, Tirane

Poysari, P. "Assessing Progress on Security Sector Reform in South East Europe", Geneva Center for European Security Policy and Defense Policy, available at: htpp:// Esdp-Course.Ethz.Ch

Ohrid Regional Conference on "Common Platform on Border Security and Management", http://polis.osce.org/library/details?doc_id= 2937\&lang_tag=\&qs=(2003)

"Bashkepunimi Rajonal per Zhvillimin dhe Integrimin Europian", (2007). AllS

"The National Security Strategy of the Republic of Albania", (2005). Albanian Defense Ministry

Batt, J. (2005). "The EU's Security Agenda and the Western Balkans", Belgrade

Thissen-Schotgerrits, M. (1999). "NATO, important factor for stability and security in the Balkans", Democracy and Security, AllS

"A Secure Europe in a Better World", (2003). European Security Strategy, Brussels

Wolfers, A. (1962). "National Security as an Ambiguous Symbol", Essay on International Politics, Baltimore: Johns Hopkins University Press

\section{Internet Sources}

www.brook.edu/views/articles/daalder/19990920FP.htm

www.ec.europa.eu/enlargement/index_en.htm

www.moa.gov.al

www.moi.gov.al

www.Gesp.Ch

www.ndc.nato,int 